\title{
CSR Implementation in Empowering Local Palm Community Economy in District Merauke (Case Study of Merauke Integrated Food-Energy Estate Project/MIFEE)
}

\author{
$1^{\text {st }}$ Alexander Phuk Tjilen \\ State AdministrationDepartment, \\ Faculty of Social and Political Science, \\ Universitas Musamus \\ Merauke, Indonesia \\ alexander@unmus.ac.id \\ $4^{\text {th }}$ Fenty Yoseph Manuhutu \\ Development Economic Department, \\ Faculty of Economy and Business, \\ Universitas Musamus \\ Merauke, Indonesia \\ joesopha2006@yahoo.com
}

\author{
$2^{\text {nd }}$ Samel Watina Ririhena \\ Development Economic Department, \\ Faculty of Economy and Business, \\ Universitas Musamus \\ Merauke, Indonesia \\ ririhena@unmus.ac.id
}

\author{
$3^{\text {rd }}$ Inez Cara Alexander Phoek \\ Saint Theresa School of Economics \\ Merauke, Indonesia \\ inezcara@gmail.com
}

\begin{abstract}
The research background is the presence of so many investors entering District Merauke by utilizing the land that belongs to the local community, the problems that arise are 1) How does the company run the CSR to be accepted by the local community? 2) How is the appropriate CSR model to be run by investors tailored to the needs of the local community in District Merauke?. The objectives of the research are 1) Exploring deeply how companies' roles involved in the MIFEE program, especially those that invest in oil palm companies, runs CSR programs involving communities as the owners of communal rights; 2) Determine the appropriate model of CSR program that is appropriate to the culture of the Papuan community, thus creating mutually beneficial relationships, especially empowerment that leads to the improvement of the community's economy. The research method used in this research is qualitative research. Research is done through field observation, literature observation, data collection, and in-depth interviews. Data obtained collected is described and analyzed by the quantitative method to formulate the model of economic empowerment.
\end{abstract}

Keywords- CSR, MIFEE, Implementation Program, Economy Empowerment, Local Community Empowerment

\section{INTRODUCTION}

Merauke Integrated Food Estate and Energy (MIFEE) was officially launched by the Minister of Agriculture on August 11, 2010, in Kampung Sirapu, District Kurik, Merauke. MIFEE was originally a proposal from Merauke Regional Government in the form of the Merauke Integrated Rice Estate (MIRE) project by admiration of large-scale paddy farming, linked to Papua 2010 Long-Term Development Plan for 2006-2011. The Central Government supported the program and issued a regulatory policy by issuing Government Regulation Number 26 Year 2008 on National Spatial and Regional Planning (RTRWN) and the
Presidential Instruction Number 5 year 2008 on Economic Programs Focus which placed Papua as a prime area with excellent agricultural, with the goal to be achieved through MIFEE is to tackle the problem of food and energy crisis, as well as an effort to save and earn foreign exchange [1]. The proposed land allocation by Merauke Regional Government for the MIFEE program amounted to $1,283,000$ ha or $28.5 \%$ of the total area of 4,500,000 ha, but the realization for the initial phase of the permitted land for MIFEE amounted to 552,000 ha or $12.3 \%$ of the total overall area 3 (meraukepos.com. February 15, 2011). In terms of business licensing, quoted from the data of the Regional Promotion and Investment Agency (BAPINDA) since the idea of the MIFEE Program was initiated in 2007 until 2010, there has been an increase in the business license. In 2006, there was only one company license and increased to seven company licenses annually in 2007, 2008 and 2009 and in 2010 increased again by 10 additional licenses [1]. MIFEE will be hosted by State-Owned Enterprises (SOEs) and Farmers Owned Enterprises (BUMP), involving large private sector through stakeholder involvement by a profitable partnership pattern. The program will also be pursued through link and match efforts in the field of human resources and technological innovation [1]. If the implementation of MIFEE goes smoothly, it is predicted that gross domestic product (GDP) per capita per year will reach USD 8280 per capita/year [1]. For comparison of 2007, per capita/year GDP per applicable price based on District Merauke was USD 900 [2].

Legal umbrella for investors who manage largescale food investment, in this case, is food estate as outlined in Presidential Instruction Number 5 Year 2008 on the focus of the 2008-2009 Economic Program that is a priority and as a continuation of Presidential Instruction Number 6 Year 
2007 on the Policy of Acceleration of Development of Real Sector and Empowerment of Micro, Small, and Medium Enterprises. The concept of food estate itself is a concept of food production development that will be done in Indonesia that is by integrating agriculture, plantation and animal husbandry in a very wide land area. Hopefully, the result of the production of food estate land can be a state supply as a form of national food security. Note that the extent of land used as a food estate project is impossible to do by farmers so it is clear that this requires managers who plan to be given to industrial companies. Based on data from the Merauke District Plantation Office in 2015 that companies engaged in palm oil plantations are focused on the locations of District Muting, District Elikobel, and District Mbuti, with total land that has been used for planting of 30,000 ha. The company can be seen in the following table:

Table 1. List of Oil Palm Plantations in District Merauke

\begin{tabular}{|l|l|}
\hline \multicolumn{1}{|c|}{ Harvested } & \multicolumn{1}{|c|}{ Harvest Ready } \\
\hline PT. Dongeng Prabawa & PT. Berkat Cipta Abadi \\
\hline PT. Bia Inti Agrindo & $\begin{array}{l}\text { PT. Agri Prima Cipta } \\
\text { Persada }\end{array}$ \\
\hline $\begin{array}{l}\text { Perusahaan Yang Dalam } \\
\text { Penanaman }\end{array}$ & $\begin{array}{l}\text { PT. Ageri Prima Persada } \\
\text { Mulia }\end{array}$ \\
\hline PT. Inter Mulia & $\begin{array}{l}\text { PT. Inter Nusa Jaya } \\
\text { Sejahtera }\end{array}$ \\
\hline PT. PAL & \\
\hline
\end{tabular}

Merauke. 2015

The field of activities directed by the Plantation Agency pursuant to Law Number 25 Year 2007 on Corporate Social Responsibility (CSR) is directed to the field of community economy, education, health, social culture, infrastructure, and environment. Based on the existing realities, the MIFEE program holds potential conflicts with the local community of the customary rights stakeholders over the land. To avoid this, the clearing of the land for plantations and MIFEE should take into account the interests of indigenous peoples. This is in line with the development that the company must pay the customary right to the owner of the land that is not small. Complaints due to the presence of MIFEE which further marginalized the role and habitat of indigenous peoples, led to protests from 27 non-governmental organizations (NGO) that demanded the closing of MIFEE to the United Nations (CERD) if it was not taken seriously by the Government [3] (kompas.com. 26 July 2013).

Seeing the condition of District Merauke and the target of achieving the success of the MIFEE program is very high, causing problems such as the use of customary land, destruction of the environment, the destruction of local people's economy, and the denial of the existence of the population which then raises the question of whether the MIFEE program can be accepted by local communities in District Merauke. To overcome various conflicts, one of the efforts that can be done is to empower local communities through CSR program. Based on the fact that the government should bridge the interests of investors and the interests of local communities through the mechanism set forth in Law Number 25 Year 2007 on Investment in Article 15 letter B affirms that "corporate social responsibility is the responsibility attached to each investment companies to create harmonious, balanced relationships, and in accordance with the environment, values, norms, and culture of local communities ".

Furthermore, Law Number 40 Year 2007 regarding Limited Liability Company (State Gazette Year 2007 Number 10, Supplement to State Gazette Number 4756); stating that a company that carries out its business activities in the field and/or related to natural resources is obliged to carry out its social and environmental responsibilities. Social and environmental responsibility is the obligation of the company budgeted and calculated as the cost of the company whose implementation is done with due attention to the decency and fairness.

\section{A. Research Objectives}

This research aims to:

1. Explores in depth how private roles involved in the MIFEE program, especially those that invest in oil palm companies, run CSR programs involving communities as owners of communal land rights.

2. Determine the appropriate model of CSR program that is in accordance with the culture of the people of Papua, so the creation of mutually beneficial relationships, especially empowerment that leads to improving the economy of society.

\section{B. Research Urgency}

Implementation of MIFEE program starting from 2010 until now, specifically engaged in oil palm plantation of 8 (eight) investors with various obstacles both lack of infrastructure available to support their activities such as roads, bridges, electricity, water (irrigation), there are also obstacles to managing land use rights even after obtaining permits from the Government, this is evidenced by various rejection from customary rights owners and the progress of slow-moving investment developments.

\section{RESEARCH METHODS}

This study was conducted using a qualitative approach, by applying several data collection and data analysis techniques. Each is (1) literature review and content analysis; (2) In-depth interview (individual); (3) Focus Group Discussion (FGD) provided by The Saint Antonius Foundation (YASANTO) involving community leaders (church / religious, tribal, and NGO representatives), and concerned government officials; (4) Detailed observations are also conducted in villages/districts that have a direct relationship with companies that use community land.

\section{RESULTS AND DISCUSSION}

\section{A. MIFEE Program}

The MIFFE Program based on the 2010 draft Regional Regulation on Merauke Integrated Food Estate and Energy Development in Merauke Regency is the development of food, livestock and fishery production located in large areas of land. At this early stage, the main focus is on food estate. MIFEE objectives based on the Regional Regulation:

a. Increase farmers' empowerment, income, and prosperity 
b. Encourage the expansion and equity of employment opportunities and employment opportunities

c. The penetration of plasma cores or entrepreneurs/investors with farmers

d. Industry development and manufacturing

e. Empowerment of micro, small and medium enterprises, and cooperatives

f. Land expansion by mechanization

g. The existence of market guarantees

The implementation of the MIFEE program commenced in 2010 and ends in 2030. The location of MIFEE land under the draft Local Regulation includes District Kimaam, District Okaba, District Nguti, District Jagebob, District Tanah Miring, District Animha, and District Muting. Food crops to be developed are rice, corn, soybeans, sorghum, wheat, vegetables, and fruits. Farms to be developed are chicken, beef, buffalo, rabbit, and quail. Plantation area consists of sugarcane, palm oil, and sago. Fisheries field consists of the land fishery and fish processing. The land used for the MIFEE program is the Area of Land Use (APL) of 1 million ha. MIFEE handling is divided into clusters. Each cluster of 200,000 ha consists of 40 clusters. Land which is in the customary right is not allowed to be sold to investors, but only used as a leasehold and lease rights so that ownership is still in the hands of local people within a certain period of time which is shared by both parties and known by the District Government.

In developing MIFEE, investors must involve local farmers. Investors partner with farmers through a plasma core pattern. Membership of the consortium, consisting of elements of government, experts, community, and college.

\section{B. Public Welfare}

Welfare theory, in general, can be classified into three kinds, namely (Albert and Hannel in Sugiarto ???):

a. Classical Utilitarian

This theory states that one's satisfaction can be measured and increased. Different levels of pleasure shared by the same individual can be compared quantitatively. The principle for the individual is to maximize his or her well being.

b. New Classical Welfare Theory

This theory explains that welfare is a function of all individual satisfaction.

c. New Contractarian Approach

The principle of this approach is that a rational individual will agree with the maximum freedom in his life. Every individual has a clear concept of goods and services and the tasks of the existing social institutions.

Based on the above three theories can be concluded that the level of one's well being is closely related to the level of satisfaction and pleasure that can be achieved in his life. In order to achieve the desired level of well being, a behavior that maximizes its satisfaction is required in accordance with the available resources. Indicators of people's welfare are population, health and nutrition, education, employment, level and consumption, housing and other social (BPS. s2007).
3. The Concept of Corporate Social Responsibility (CSR) The concept of CSR involves partnership responsibilities between government, institutions, community's resources, as well as local communities. This partnership is neither passive nor static. This partnership is a shared social responsibility among stakeholders. The concept of CSR in Indonesia is actually not a new thing, because CSR has been known and practiced since around 1970's. In its classical sense, CSR is still perceived of a charity from the entrepreneurs to the community around where the company operates. The concept of CSR implementation for Indonesia is based on Law Number 40 the Year 2007 regarding Limited Liability Company (Statute Book Year 2007 Number 10, Supplement to Statute Book Number 4756); stating that, a company that carries out its business activities in the field and/or related to natural resources is obliged to carry out its social and environmental responsibilities. Social and environmental responsibility is the obligation of the company budgeted and calculated as the cost of the company whose implementation is done with due attention to the decency and fairness. But it has not been implemented in unison and there is no operational guidance that is the standard size. There is an emergence of corporate awareness that its success in achieving goals is not only influenced by internal factors alone, but also by the communities around it. In this case, there has been a change in the relationship between the corporation and the community. The corporation that originally positioned itself as a donor through charity (philanthropy) and philanthropy (humanitarian) activities, has now positioned the community as a partner who contributes to the continuity of corporate existence and as a CSR strategy that it runs as a benchmark for achieving success in running its activities. According to Kotler and Nancy (2005), CSR is defined as the company's commitment to improve community welfare through good business practices and contribute some of the company's resources. Philip Kotler and Nancy Lee mentioned some of the benefits that can be gained when a company integrates CSR into their business operations and strategies:

a. Increase sales and stock prices

b. Strengthening brand position

c. Enhancing corporate influence and reputation

d. Enhance the ability to attract, motivate, and maintain employees

e. Lower operating costs

f. Increasing attractiveness to investors and financial analysts

The background of why companies need to consider social responsibility consists of various reasons in the implementation, for example, because there are issues of pluralism, reputation, the demand of public opinion, and licenses to operate. These issues form the basis for the company or organization to carry out its social responsibilities. The issue of reputation becomes an important part of the company's consideration of doing social responsibility.

\section{Implementation of Corporate Social Responsibility (CSR)} Program

Sen and Bhattacharya identified six main programs included in CSR, namely: 
a. Community support, including support for educational programs, health, cultures, etc.

b. Diversity is the company's policy of not discriminating between consumers and prospective workers in terms of gender, physical (disability), or into certain races.

c. Employee support, in the form of protection to workers, incentives, and awards, and safety assurance.

d. Environment, creating a healthy and safe environment, managing waste well, creating eco-friendly products, etc.

e. Non-U.S. operations, meaning that the company is responsible for providing equal rights for the world community to get the opportunity to work, among others, by opening a factory abroad (abroad operations).

f. Product means the company is obliged to make products that are safe for health, do not cheat, do research and product development continuously and use recycled packaging.

Ernst and Young argue that the company has four main responsibilities: employees, consumers, society, and the environment. These four things can be the basis of consideration for the company to establish the core program in implementing specific CSR. There are nine work programs that can be done company in carrying out CSR activities are:

a. Employee Programs

Employees are a valuable asset to the company, so it is not surprising that the company is very concerned about the development of employee competency and welfare. Attention to the welfare of employees needs to be expanded not only from the side of health and safety assurance but needs to expand the program such as work-life balance program and decision making empowerment program.

b. Community and Broader Society

The majority of companies have activities in this area, one of them is through community empowerment which is how individuals, groups or communities try to control their own lives and work to shape the future according to their wishes (Shardlow 1998 in Ambadar, 2008). Implementation of community empowerment through development projects that enable community members to gain support in meeting needs. Other responsible parties can meet campaigns and social actions that enable these needs.

c. Environment Programs

Programs related to the maintenance of the environment e.g. by producing products that are safe, harmless to health, and environmentally friendly; making absorption wells; and waste disposal well.

d. Reporting and Communications Programs

The company issues or reports the results of its CSR activities through the annual CSR report so that there is real evidence of corporate participation in carrying out its social responsibilities.

e. Governance or Code of Conduct Programs

The company focuses on social activities that are conducted based on government-regulated systems. The main thing to be aware of is how stakeholders, governments, communities, and businesses can create mutually agreed regulations or provisions to streamline
CSR programs. This means a law is required to regulate CSR at a macro level such as the objectives of the CSR program, the program's success assessment standard, and coordination with related parties.

f. Stakeholder Engagement Programs

Efforts to create an effective engagement program as the key to achieving success CSR strategy and sustainability strategy.

g. Supplier Programs

Promoting good relationships based on trust, commitment, sharing of information between the company and its business partners, for example through the management of the supply chain or business network.

h. Customer / Product Stewardship Programs

The need for corporate attention to consumer complaints and product quality assurance produced by the company.

i. Shareholder Programs

Improved share value program for shareholders, because shareholder is a priority for the company.

\section{Corporate's CSR in Environmental Maintenance Efforts}

Corporate CSR activities in the field of the environment including infrastructure development in the form of road and bridge construction, residential development and village hall for the community. Land used for roads are not maximal because the community is not assisted by means of transportation from village to city so that CSR activity is considered not maximal. The construction of village halls is not accompanied by corporate activities/ training to educate and enrich the community with other skills so that they no longer depend on the natural yields produced by the land that currently used by the company for the MIFEE program. Land used in the form of large forests causes changes in ecosystems in the neighborhood, where the indigenous people work in the area are a naturalist who takes crops directly from the forest as a livelihood. These ecosystem changes make the natural springs of river dried up, therefore, the fish and animals do not get enough water, some die, some migrate, consequently, the local community can no longer harvest corps from the environment in which they live, the cases that occur to the nutrients bad and hunger experienced by the local community due to the scarcity of food sources.

Corporate CSR in Community Empowerment Efforts in the Social Sector

The company has CSR activities in the social field covering various activities such as religion, health, and education. The religious field includes building churches (the majority religion in which the company operates is Catholic) and provides assistance to the churches in which the company operates. The health sector includes clinic development and activities such as Supplementary Feeding Program (PMT) through Posyandu (assistance center for families in the neighborhood), and the socialization of disease prevention. The field of education includes school construction and assistance to the schools in which the company operates. 
However, companies have not / cannot employ local people like the rules written by Ernst and Young, to be able to employ local people, companies should be assisted by the government to improve the quality of education and provide training so that the company not only uses community land but educates and trains people in the neighborhood to gain certain level of expertise to be used for working within the company activities and also to helps local people to be able to produce products and money from land use. Based on the field observations, although the company has conducted CSR activities in the social field, the impacts that occur in the environmental field make CSR activities in the social field is not yet maximal; by the case of malnourished and hunger even though the company has provided programs that support public health; incomplete dietary supplements such as instant foods also undermine the natural culture of society and worsen public health. Development and assistance to schools are not supported by means of transportation to bring students to school. Natural indigenous cultures such as livelihoods as gatherers, food sources derived from nature, dwellings far from the city, belief in mystical things are very different from firms filled with urban people with education and advanced cultures, making CSR activities considered by the company have met the standards to be irrelevant. A non-fundamentally firm approach by not trying to change the mindset, cultures, and educating the public to be open to science, ultimately giving no meaningful progress to the local community.

\section{Government Involvement on Corporate CSR Activities}

Although there are laws of the Republic of Indonesia that specifically regulate the CSR activities of the company in the place where the company is operating, but there is no agency specifically appointed to evaluate corporate CSR activities in Indonesia. Corporate CSR activities are supposed to be in accordance with the conditions of society whose land is used by the company, given that each region has different climates and cultures, making people from one region to another have different behaviors. The company should conduct a survey and study the community so that CSR activities are well targeted, the government, as an agent who takes the side of the community should assist the company. The company also did not report sufficient results and communications to the local community as written by Ernst and Young. The local community is not supported by the government to have an agency that can accommodate information and complaints from the community about CSR activities occurring in their residence, or an agent who can act as an advocate or mediator in case of conflict between the company and the community. The Law of the Republic of Indonesia governing CSR activities does not clearly impose sanctions on companies that fail or lack in CSR activities so that CSR activities of the company are not totally executed.

\section{CONCLUSION}

The results show that the government regulation on CSR does not impact CSR practices, so force forces exist, but there is no sanction. In contrast, firm commitment and strategy are the decisive factors in CSR practice success. Implementation of CSR is still charity rather than philanthropic, the impact of CSR implementation has not had a good impact, which brings changes and advancements for local communities, and even tends to be detrimental. The input that can be given by the researcher is 1) considering that the local community professions as gathers then the company should openly report the company's performance result periodically and apply the 'profit share' system and give 'financial aid' to the community in order to obtain the results directly and given education to use the money maximally, 2) the company provides education and training to the community so that the community can have other capabilities and skills such as farming and selling the crops supported by facilities (transportation) and infrastructure (roads and bridges) by the company in the eye field the livelihood is no longer maximized, 3) it is time for the government to set up an agency to learn the culture of the local community and oversee the company's CSR program, so that the programs that are run on target and beneficial to the local community.

\section{ACKNOWLEDGMENT}

We thank Universitas Musamus for facilities, supports, and publications.

\section{REFERENCES}

[1] Z. et Al, MIFEE: Tak Terjangkau Angan Malind. 2011.

[2] "No Title," http://papua.bps.go.id.

[3] "Target Papua Mandiri dan Sejahtera Harus Terwujud," Kompas, 2012.

[4] D. Sugiarto, Manajemen Sumber Daya Manusia. 2007.

[5] "No Title," http://ipm.bps.go.id/page/ipm.

[6] Undang-Undang Nomor 40 Tahun 2007 tentang Perseroan Terbatas (Lembaran Negara Tahun 2007 Nomor 10, Tambahan Lembaran Negara Nomor 4756. 2007.

[7] N. Kotler, P \& Lee, Corporate Social Responsibility: Doing The Most Good For Your Company And Your Cause. 2005.

[8] J. Ambadar, CSR Dalam Praktik Indonesia”. 2008. 2008. 